\title{
Respect as an Ethical Principle in System Development
}

\author{
Thiago Ferreira de Toledo
}

\begin{abstract}
The ethical formation of an individual depends basically on the cultivation of moral qualities. The conduct influences the professional performance. Therefore, this work suggests the ethical principle of respect as a factor to be considered when creating systems using Scrum's Agile Development framework, because if there is good communication and acting with respect, it is possible maintain well-being in the workplace.
\end{abstract}

Keywords-Computer Ethics, Ethics, ICT, Scrum.

\section{INTRODUCTION}

Ethics has become a much debated topic in public and private life sectors, perhaps resulting from the ethical crisis, where there is a great diversity of ethical conceptions, wherein, not infrequently, they are antagonistic. Adding to this, the fragmentation of values erodes the means by which there could be a rich exchange of ideas [1].

In this scenario, where the dialogue has become complex, in the sense that there is no effective communication because of the different concepts, the friction between ideas makes exchange difficult, which is essential for human evolution.

In view of this, as our civilization is increasingly immersed in technological resources and information technology is being widely introduced in the most varied sectors of society, the debate on ethical issues concerning the use of Information and Communication Technology (ICT) is of fundamental importance, to support, with solid concepts, good practices in its use.

That said, the central focus of this work, in a broad sense, it is about the application of ethical principles in environments where there are ICT resources, and, more specifically, of how to insert an ethical principle, respect, during software development, considering Scrum, which is the name given to the methodology to manage and develop software projects.

To achieve this goal, the following section will explain the concepts of ethics and morals, applied ethics, computer ethics and other terms that are used in the area. In Section III, related works on this theme are described. In Section IV, points of related work, which have somehow contributed to this research, are noted. Next, it is reported how respect can influence conduct and, in this way, consider it as a principle during software development (Section V). Finally, in Section VI, final considerations are described, because a topic as comprehensive, as an ethical principle, cannot be exhausted.

Manuscript received September 9, 2020.

Author is Master in Electrical and Computer Engineering.

\section{FROM ETHICS TO COMPUTER ETHICS}

As a starting point, I quote the words of Carlos Bernardo González Pecotche, Argentine thinker and humanist, founder of the Logosophical Science, affirming "[...] that the ethical formation of a person depends on certain factors and, very specially, on the development of his moral and sensitive qualities." (p. 88) [2]. And, about morality, for being closely related to ethics, Pecotche [2] announces: "Logosophy declares that morals arise in the individual from the excellences of his innermost feelings." (p. 80). Thus, ethics is the way the individual acts, according to what he has internal values, acquired through the cultivation of moral qualities and high feelings.

Then, as a way of providing categories and procedures to guide what is ethically relevant, ethical theory emerged [3]. And, its application, that is, the ethics applied, aims to seek the best ways to insert ethical theories into professional practices, or fields of human activity. As a result, it is expected to find a renewable set of policies and good practices [4].

The application of ethics to guide ICT professionals to develop their activities with good conduct, is called computer ethics, in which conceptual models are proposed for the understanding of ethical problems involving computer technologies. The conceptual model considers different policies on what the human being values and what he does not value [3]. In view of this, computer ethics urges scholars to review computational technology and its values to provide principles for understanding, conceptualization and use of computational technology [5].

Within the context of computer ethics, there are other terms that also characterize it, for example, information ethics, computer and information ethics (or information and computer ethics) [4]. Regarding the term computer and information ethics, in a broad sense, it can be considered as the branch of applied ethics that studies and analyzes the social and ethical impacts on the use of ICTs [6].

Introduced the main concepts that underpinned this work, the following are some works, in which the authors have focused on the subject, to propose ideas or suggestions to be considered concerning the application of ethical aspects in the area of ICT.

\section{RELATED WORKS}

Johnson [7], already in the 1980s, expressed concerns about the way individuals would relate to each other and to organizations, due to the introduction of computers; in view of this, she also noted the change of rights and responsibilities in these relationships. The author then suggested that a 
philosophical and ethical analysis is necessary when there is a not so obvious situation, or when it is necessary to harmonize whenever principles enter into conflict, for example, property, privacy and power; that is, the power that organizations have come to possess because of the use of computer resources.

Friedman e Nissenbaum [8], analyzed real cases and identified three categories of bias in computer systems; a preexisting one, with roots in social institutions, practices and attitudes; the technical bias, which arises from technical restrictions or considerations; and the emerging bias, which is evident in a context of use. As a proposal to try to avoid the identified biases, the authors suggested the inclusion of criteria to be considered in system development, such as: reliability, accuracy and efficiency.

Huff [9], suggested a principle, which applies to all acts of the individual, which is responsibility; he also emphasized the importance of being responsible and being aware of the possible consequences of our actions. And, specifically in relation to the development of computer programs, during the project phase, it is important to recognize the problem and limit its domain. During development, use methods to inform yourself about possible effects that may occur. And, when the program is launched, provide a social impact statement and be prepared to correct any failures as soon as possible.

Brey [10], suggested embedding key values in systems, applications and computational practices, being: justice, autonomy, democracy and privacy. And in relation to research in computer ethics, the author maintains that they should be multilevel and interdisciplinary, with a level of disclosure, the theoretical level and that of application.

Friedman, Kahn Jr. and Borning [11], have developed an approach called Value Sensitive Design ${ }^{1}$. The methodology consists of conceptual, empirical and technical investigations, and that considers human values such as justice, responsibility and support for the democratic process.

Rehg [12], examined the ethics of discourse and outlined a scheme that is responsive to the actual state of discussion, whose purpose is to enable its use not only by project managers and policy makers, but also by any citizen or interested party in assessing the acceptability of a cyber practice.

Buzato [4], investigated theoretical and practical aspects, from the perspective of ethics applied to ICTs. For this, they were considered traditional philosophical norms applying them to new situations difficult to identify by known analogies. In other words, there must be an interdisciplinary engagement between researchers of the human sciences and exact sciences to work together, considering the moral philosophy and the metaethics, to discover what they can and cannot offer.

Tavani [13], suggested the insertion of a component, called Critical Reasoning, as part of a methodological framework of ethics applied to ICT. According to the author, this component provides a systematic method to detect logical fallacies and also provides techniques to test our own arguments to ensure they do not contain fallacies. In addition, Critical Reasoning provides a methodology to build arguments to defend your own points of view.

After this brief description on research focused on ethical issues applied to digital technologies, in the following section

\footnotetext{
${ }^{1}$ https://vsdesign.org/
}

are outlined considerations about the related works.

\section{RELATED WORK CONSIDERATIONS}

In relation to the research reported in this work, relevant points were considered, such as the concern to analyze rights, responsibility, property, privacy and power [7]; reliability, precision and efficiency [8]; responsibility [9]; justice, autonomy, democracy and privacy [10]; justice, responsibility and support for the democratic process [11].

There are principles that have been investigated by different authors, and this is perfectly understandable, because there are values common to all human beings. Therefore, an important point to consider is to find out what these common values are and to create an effective dialogue so that there is an exchange rich in ideas and mutual understanding.

The understanding will be effective through good communication, transparent and fair. For example, Rehg [12] has created a framework that produces scalar measures to support the distinction between opinions, placing them as unsustainable, defensible and strong. Tavani [13] emphasized the importance of immunizing against fallacies when analyzing works and avoiding them in our own arguments. The author also says about the need to support the arguments on solid grounds, with good arguments.

Relating responsibility to communication, another point to note is the seriousness with which data should be stored, because when they are used, for example, to support decision making, the result obtained will communicate something, extracted from its analysis, and if they are analyzed based on incorrect data, the communication will not be adequate and people may be harmed.

Having responsibility in communication is an indication of the principle of respect. Therefore, in the following section, this principle will be considered as a suggestion to enhance some aspect of the Scrum development method.

\section{A NEW QUESTION IN SCRUM MEETING}

Scrum is an Agile Software Development method. Agile Development combines philosophy with a set of software development principles. The philosophy is to stay focused on customer satisfaction and incremental delivery; the client receives a new functionality, or system module, as they are completed by the development team, not having to wait for the entire system to be completed to deliver it. The Agile methodology prioritizes small and motivated teams that use informal methods, minimal software engineering resources, and above all, simplicity in developing the computational solution. In this development modality, there must be an active and continuous communication between developers and clients [14]. The most popular Agile Development methodology is Scrum [15].

Scrum framework was chosen because it is the most widely used among the options available in the Agile Development methodology. And, Agile Development was used as an example, because it is a dynamic method that requires constant communication between team members and with customers, so there is constant human contact.

Scrum emphasizes the use of efficient software process standards when dealing with a project with little time 
availability, changing requirements and urgency in the business. Each process standard defines a set of activities [14]:

- Backlog: is a list containing the requirements or functionalities of the project;

- Sprint: are units of work needed to achieve the objective defined in a requirement established in the work record (Backlog);

- Scrum Meetings: are daily meetings, usually of short duration, in which all team members answer questions asked by Scrum Master.

Scrum Master performs the same function as a project manager or a technical leader, whose main function is to ensure that the team respects and follows the values and practices of the Scrum methodology. The Scrum Master is a facilitator, responsible for assisting all team members in their difficulties, and is also the one who organizes the Scrum Meetings [16].

In short, Scrum is used to guide the development activities of: requirements, analysis, design, evolution and delivery. In each of these activities specific tasks occur, which consists of work units to achieve a requirement established in the work record. At the end of each working day, meetings take place in which Scrum Master asks three questions to each team member [14]:

1. What have you accomplished since the last team meeting?

2. What obstacles are you encountering?

3. What do you plan to do until the next team meeting?

Such questions aim to update all team members on the progress of individual activities, focusing on technical issues of the project. In view of this, a new question can be formulated with focus on the user, which is effectively who will use the system.

In the research conducted by Nelson et al. [17], the authors argued about the importance of keeping the team confident so that the organization achieves its objectives and the respect needed to cultivate the well-being. In this way, as Scrum prioritizes urgent projects, with time restrictions and which may change during its development, it is important that there is respect among team members to maintain welfare.

Other factors are important to maintain well-being, for example, as reported in the research by Rogers and Ashforth [18], lack of respect can affect a person's need to feel part of the team, as well as damaging self-esteem and psychological security.

When any member of the team has their self-esteem and psychological safety affected, their performance may be impaired, which may compromise the success of the project. Therefore, maintaining respect may prevent or minimize these unwanted side effects.

Respect is related to the good coexistence between people: "There is no law that commands respect, well it can be said, it responds to a natural law. At all times, respect was the indispensable means that made the coexistence between human beings achievable."2 (p. 176; Author translation) [19].

Respect being a natural law, and an ethical principle, its

\footnotetext{
${ }^{2}$ In Portuguese language: "Não existe uma lei que imponha o respeito, porquanto, bem se pode dizer, ele responde a uma lei natural. Em todos os tempos, o respeito constituiu o meio imprescindível que fez realizável a convivência entre os seres humanos."
}

cultivation in life will support the individual's other actions. In this way, having respect as a rule of personal conduct, it can be reflected, including, in the professional performance, helping to maintain the welfare within the team.

A respectful attitude practiced individually may help to tolerate when points of view diverge, because, as expressed by Winck et al. [1], an ethical crisis generated from a great variety of concepts, antagonistic to each other, may hinder human coexistence, shaking the foundations of civilization. So, respect is an important point in order to have a healthy dialogue that allows harmonic communication between individuals.

After this brief analysis about respect, as a suggestion, the question to be included int the Scrum Meeting is the following: What did you do in respect to the user?

This constant reminder, of respect to the user, may contribute to the emergence of ideas to improve some process, functionality, etc., or that of finding a more viable and suitable solution, which have not been previously identified in the initial phases of the project. In addition, it may promote reflection in each member of the team, reminding them of their responsibility at work, which, as Huff [9] rightly said, software designers and other computer professionals have a kind of unintended power, which is the ability to affect others, even if not the intention, because computers instrument human action.

Huff's considerations, made in 1996, about the recommendations of post-launching the system, that it is important to prepare a social impact statement, as well as to be prepared to correct any problems [9], comes in line with recent research in order to identify possible failures that may occur. For example, considering the systems in use, obviously ethical considerations should not be neglected, on the contrary, one should be prepared to identify and remedy them. However, when ethical issues occur that may not have been identified in advance before the development or deployment of the system, researchers have used quantitative and qualitative methods to analyze incidents, failures or a set of previous experiences in order to identify issues or perspectives that may help avoid future difficulties [20].

Exercising the work, based on respect for the person, - in the context of this work, to the user of the software -, maybe a greater sense of responsibility will be promoted in the members of the development team, reminding them that the product of their work will directly reflect other people.

Lastly, in the next section, final considerations are reported.

\section{FINAL CONSIDERATIONS}

This work focused on the importance of maintaining respect in the workplace, using as an example, introduce respect as a new element in a widely known software development methodology.

In order to have a good coexistence, one starts from a good communication, therefore, in order for professionals working directly or indirectly in ICT to maintain well-being in their workplace, it is important to consider good ethical conduct expression of individually cultivated moral values - and thus, being able to reflect on his professional performance.

The suggestion presented in this work, is to consider the cultivation of respect as an internal value, for it is a source that will help in the harmonious coexistence among individuals, 
and, consequently, in the professional field. Furthermore, to keep the team motivated, it is necessary that team members are confident, feel part of the team and are treated with respect so that the objectives of the organization or team can be achieved, and above all, maintaining the welfare of all team members.

Ethics, with its principles, is an inexhaustible subject, because, as long as there is interaction between human beings, a respectful and cordial coexistence will be necessary.

\section{ACKNOWLEDGMENT}

I thank André Reguero Marques for reminding me, in one of our studies at the Logosophical Foundation, of the superior ethical principles of respect, tolerance and freedom.

\section{REFERENCES}

[1] O. L. Winck et al. Philosophy of Education [Filosofia da Educação]. $1^{\text {st }}$ ed. Curitiba, Brazil: IESDE Brasil, 2018, p. 187.

[2] C. B. G. Pecotche. Initiation Course into Logosophy. Translated from Spanish by members of the Logosophical Foundation - For Man's Self Elevation. $3^{\text {rd }}$ ed. São Paulo, Brazil: Editora Logosófica, 1963. Translation: Curso de iniciación logosófica.

[3] J. H. Moor. "What is computer ethics?". Metaphilosophy, vol. 16, n. 4, pp. 266-275, 4 Oct. 1985. https://doi.org/10.1111/j.1467-9973.1985.tb00173.x

[4] M. Buzato. (September 2016). Towards an Interdisciplinary ICT Applied Ethics: Language Matters. Revista Brasileira de Linguística Aplicada. [Online]. Belo Horizonte, Brazil, vol. 16, n. 3, pp. 493-519. Available: http://www.scielo.br/scielo.php?script=sci_arttext\&pid=S1984-6398201 6000300493\&lng=en\&nrm=iso. Accessed: Sep. 5, 2020. https://doi.org/10.1590/1984-6398201610240

[5] A. Kuzu. "Problems Related to Computer Ethics: Origins of the Problems and Suggested Solutions". Turkish Online Journal of Educational Technology, vol. 8, n. 2, Apr. 2009.

[6] T. Bynum. (October 2015). Computer and Information Ethics. The Stanford Encyclopedia of Philosophy. Summer 2018 Edition. Available: https://plato.stanford.edu/archives/sum2018/entries/ethics-computer/. Accessed: Sep. 5, 2020.

[7] D. G. Johnson. "Mapping Ordinary Morals onto the Computer Society: A Philosophical Perspective". The Society for the Psychological Study of Social Issues, vol. 40, n. 3, pp. 63-76, 1984. https://doi.org/10.1111/j.1540-4560.1984.tb00192.x

[8] B. Friedman, and H. Nissenbaum. "Bias in Computer Systems". ACM Transactions on Information Systems, vol. 14, n. 3, pp. 330-347, Jul. 1996. https://doi.org/10.1145/230538.23056

[9] C. Huff. "Unintentional Power in the Design of Computing Systems". ACM SIGCAS Computers and Society, vol. 26, n. 4, pp. 1-9, Dec. 1996. "This version has been somewhat modified from that original version and includes new references and text." (2003). https://doi.org/10.1145/242889.242890

[10] P. Brey. "Disclosive Computer Ethics". ACM SIGCAS Computers and Society, vol. 30, n. 4, pp. 10-16, Dec. 2000. https://doi.org/10.1145/572260.572264

[11] B. Friedman, P. H. Kahn Jr., and A. Borning. "Value Sensitive Design and Information Systems," in Human-Computer Interaction in Management Information Systems: Foundations, $1^{\text {st }}$ ed, P. Zhang, D. Galletta, Ed. New York: M.E. Sharpe, 2006, ch. 16, pp. 348-372.

[12] W. Rehg. "Discourse Ethics for Computer Ethics: A Heuristic for Engaged". Ethics and Information Technology, vol. 17, pp. 27-39, Dec. 2015. https://doi.org/10.1007/s10676-014-9359-0

[13] H. T. Tavani. "Incorporating a Critical Reasoning Component into the ICT-Ethics Methodological Framework: A Case Study". The ORBIT Journal, vol. 1, n. 2, pp. 1-17, 2017. https://doi.org/10.29297/orbit.v1i2.55

[14] R. S. Pressman., and B. R. Maxim. Software Engineering: A Practitioner's Approach. Translated by João Eduardo Nóbrega Tortello. [Engenharia de Software: Uma Abordagem Profissional]. $8^{\text {th }}$ ed. Porto Alegre, Brazil: AMGH, 2016.
[15] J. Gido, J. Clements, and R. Baker. Successful Project Management. Translated by Solagen A. Visconte. [Gestão de Projetos]. $7^{\text {th }}$ ed. São Paulo, Brazil: Cengage, 2018

[16] Desenvolvimento Ágil. Scrum Master. Agile Development. [Desenvolvimento Ágil]. $2014 . \quad$ Available: https://www.desenvolvimentoagil.com.br/scrum/scrum_master. Accessed: Sep. 8, 2020.

[17] J. L. Nelson. et al. "Trust and Respect at Work: Justice Antecedents and the Role of Coworker Dynamics". Work and Occupations, vol. 46, n. 3, pp. 307-338, 2019. https://doi.org/10.1177/0730888419835261

[18] K. M. Roger, and B. E. Ashforth. "Respect in Organizations: Feeling Valued as 'We' and 'Me'". Journal of Management, vol. 43, n. 5, pp. 1578-1608, 2017 https://doi.org/10.1177/0149206314557159

[19] C. B. G. Pecotche. Logosophy Magazine Collection: Tomo I. Translated by José Dalmy Silva Gama. [Coletânea da Revista Logosofia: Tomo I]. $1^{\text {st }}$ ed, São Paulo, Brazil: Editora Logosófica, 1980. Translation: Coleccíon de la Revista Logosofia.

[20] H. Hochheiser, and R. Valdez. "Human-Computer Interaction, Ethics, and Biomedical Informatics". IMIA Yearbook of Medical Informatics, vol. 29, n. 1, Aug. 2020.

https://doi.org/10.1055/s-0040-1701990 